\title{
P. Citati, Balzac e il rosso
}

\section{Marco Stupazzoni}

\section{OpenEdition}

\section{Journals}

\section{Edizione digitale}

URL: http://journals.openedition.org/studifrancesi/10671

DOI: 10.4000/studifrancesi. 10671

ISSN: 2421-5856

\section{Editore}

Rosenberg \& Sellier

\section{Edizione cartacea}

Data di pubblicazione: 1 décembre 2017

Paginazione: 566

ISSN: 0039-2944

\section{Notizia bibliografica digitale}

Marco Stupazzoni, «P. Citati, Balzac e il rosso», Studi Francesi [Online], 183 (LXI | III) | 2017, online dal 01 février 2018, consultato il 22 janvier 2021. URL: http://journals.openedition.org/studifrancesi/10671 ; DOI: https://doi.org/10.4000/studifrancesi.10671

Questo documento è stato generato automaticamente il 22 janvier 2021.

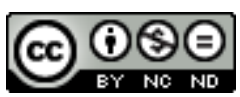

Studi Francesi è distribuita con Licenza Creative Commons Attribuzione - Non commerciale - Non opere derivate 4.0 Internazionale. 


\title{
P. Citati, Balzac e il rosso
}

\author{
Marco Stupazzoni
}

\section{NOTIZIA}

PIETRO CITATI, Balzac e il rosso, in Sogni antichi e moderni, Milano, Mondadori, 2016, «Saggi», pp. 248-253.

1 Vista con gli occhi del flâneur, Parigi, così come la descrive Balzac nella trilogia dell'Histoire des Treize e, in modo particolare, in Ferragus e ne La Fille aux yeux d'or giudicati da Citati come veri e proprî capolavori narrativi -, si presenta sotto il segno della contraddizione. Gli intensi e bizzarri contrasti di luce e di ombra, di colori e di sensazioni fanno della capitale francese un corpo «enorme e mostruoso» (p. 249), pervaso, non soltanto dagli splendori dell'oro e del piacere, ma anche dalle miserie e dai misteri più reconditi degli uomini e degli ambienti. Anche l'intreccio romanzesco riflette l'effetto complessivo di questi dettagli frequentemente in opposizione tra loro: «abbiamo sempre l'impressione, scrive Citati, che tutto si sciolga nell'aria e nell'inconsistenza; salvo che, esattamente al contrario, il romanzesco produce l'enorme gravezza della visione infuocata» (p. 250). È il caso di Ferragus, in cui «le passioni straripano e devastano i cuori» (Ibid.) o de La Fille aux yeux d'or, "pura esplosione di genio» narrativo dove il rosso della passione e del desiderio erotico estremo conosce la sua ultima trasfigurazione nel colore di una furiosa violenza omicida senza limiti e senza freno. 